\title{
SYNTHESIS OF IMMUNOGLOBULINS IgG, IgM AND IgA DURING THE ONTOGENY OF FOETAL PIGS
}

\author{
J. FRANZ, A. MILON, H. SALMON \\ Veterinary Research Institute, 62132 Brno, Czechoslovakia, Station de Virologie et d'Immu- \\ nologie, Thiverval-Grignon, France
}

Received February 22, 1982

\begin{abstract}
Franz J., A. Milon, H. Salmon: Synthesis of Immunoglobulins IgG, IgM and Ig $A$ during the Ontogeny of Foetal Pigs. Acta vet. Brno, 51, 1982: 23-30.

Using the modified micro-ELISA (enzyme linked immunosorbent assay) on the competitive principle immunoglobulins IgG, IgM and IgA were demonstrated in the blood serum, amniotic fluid and organ suspensions of 50- to 150-day old pig foetuses. The predominant immunoglobulin (Ig) in the blood serum and amniotic fluid of foetal pigs between 50 and 105 days of gestation was IgG. On the other hand, IgM prevailed in the suspensions of foetal organs up to 80 days of gestation. On the 105th day of gestation mutual ratios of the individual $\mathrm{Ig}$ classes in the suspensions of foetal organs, except the thymus, changed in favour of IgG. There were significant changes in the concentration of IgG, IgM and IgA during the period under study.
\end{abstract}

Foetal pig, IgG, IgM, IgA, ELISA.

Transfer of proteins from dam to foetus has not been demonstrated in animals with the epitheliochorial placenta which include the pig (Sterzl and Silverstein 1967). Foetal pigs are therefore not affected by maternal immunoglobulins during their intra-uterine life. All serum proteins of foetal pigs are produced by the foetuses themselves and their immune response and, consequently, synthesis of immunoglobulins are therefore unaffected by the presence of maternal antibodies. For this reason, the foetal pig is an excellent model for studies of defence mechanisms in both human and veterinary medicine and has been receiving due attention as to the development of immunity.

From a number of studies concerned with the incidence of immunoglobulins in foetal pigs and colostrum-deprived piglets (Šterzl et al. 1960; Franěk et al. 1961; Sokol and Durikovic 1967; Menšík und Franz 1969; Prokešová et al. 1969, 1970; Porter 1969; Franz and Menšík 1971; Prokešová and Rejnek 1971, 1973; Bourne et al. 1974) it appears beyond doubt that their sera contain immunoglobulins, though in low concentrations. However, up to now there has been no unequivocal answer to the question what are the quantities and mutual ratios of individual immunoglobulin ( $\mathrm{Ig}$ ) classes, depending upon the age of the foetus.

The object of the present'study was to extend contemporary knowledge on the ontogeny of the synthesis of IgG, IgM and IgA by their quantification in the blood serum, amniotic fluid and suspensions of some organs of foetal pigs from 50 to 105 days of gestation.

\section{Materials and Methods}

\section{Experimental Animals and Preparation of Samples for Analysis}

The experiment involved three groups of pig foetuses obtained by hysterectomy at 50,80 and 105 days of gestation. Each group comprised 24 foetal pigs of 3 litters (8 foetuses of each litter). Collection was made of the amniotic fluid, blood, liver, lungs, intestine, spleen and thymus of each foetus. Serum was prepared from the blood. Organ specimens were weighed and homogenized 
in phosphate-buffered saline (PBS), pH 7.2, which contained 0.05 per cent Tween 20 (PBSTween). Pooled samples were prepared from the spleens and thymuses, representing each litter. The remaining organ suspensions, blood sera and amniotic fluids were processed from each animal separately. Organ suspensions were frozen at $-60^{\circ} \mathrm{C}$, thawed, treated with ultrasound and centrifuged at $40.000 \mathrm{~g}$. The supernatants were tested for IgG, IgM and IgA content.

Preparation of Monospecific Antisera

Isolation of Immunoglobulins and Preparation of Heavy Chains

For isolation of IgG and IgM, freshly obtained pig blood serum was chromatographed on an Ultrogel ACA-22 (LKB) column. The fraction rich in IgG was precipitated with ammonium sulphate, dialysed and separated on a DEAE-cellulose (Whatman DE 52) column. Protein eluted with 0.01 mol. $1^{-1}$ phosphate buffer $(\mathrm{pH} 7.2)$ was rechromatographed on Ultrogel ACA 22. The protein fraction thus obtained contained pure IgG.

IgM was obtained by separation of contaminating alpha $_{2}$-macroglobulin by means of repeated gel chromatography on an Ultrogel ACA-22 column of the protein fraction rich in IgM.

IgA was prepared from pig milk whey by separation od DEAE-cellulose (Whatman DE 52). The protein fraction eluted with $0.125 \mathrm{~mol} .1^{-1}$ phosphate buffer, $\mathrm{pH} 7.2$, was concentrated and rechromatographed on an Ultrogel ACA 22 column.

Heavy chains of IgG and IgM were obtained by S-sulphonation of immunoglobulins and subsequent gel chromatography on Sephadex G-100 (Pharmacia, Uppsala) in 0.05 mol . $1^{-1}$ formic acid and 5 mol. $1^{-1}$ urea (Franèk and Zorina 1967). The resultant solutions of pig $\gamma$ - and $\mu$ -chains were lyophilized.

\section{Immunization of Rabbits and Saturation of Antisera}

Rabbits were immunized intramuscularly with $1 \mathrm{mg}$ doses of resolubilized $\gamma$ - and $\mu$-chains or purified IgA in complete Freund's adjuvant at three fortnightly intervals (Metzger and Houdayer 1972). They were exsanguinated one week after the last immunization.

Ig fractions of rabbit antisera were obtained by precipitation with ammonium sulphate. After dialysis their anti-L activity was removed by saturation.

Anti-IgG and anti-IgA sera were saturated by means of affinity chromatography (Axen et al. 1967) with purified IgM coupled to $\mathrm{CNBr}$-Sepharose 4B.

Anti-IgM serum was saturated in the same way using CNBr-Sepharose $4 \mathrm{~B}$ with coupled IgG and $\alpha_{2}$-macroglobulin.

\section{Preparation of Conjugate}

Purified IgG, IgM and IgA were conjugated with alkaline phosphatase (Sigma, type VII) using glutaraldehyde (Avrameas 1969). To the mixture of $0.5 \mathrm{mg}$ immunoglobulins and $1.5 \mathrm{mg}$ alka-

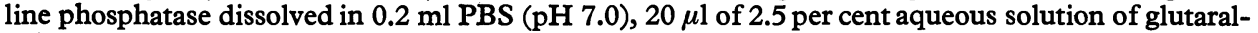
dehyde was added. After incubation for 2 hours at laboratory temperature the conjugate was dialysed for 2 days against PBS at $4^{\circ} \mathrm{C}$.

Optimum working dilution of the conjugate $(1: 200)$ had been determined in preliminary experiments.

\section{Determination of Ig Concentration by Enzyme Linked Immunosorbent Assay (ELISA)}

The detection was made with the modified micro-ELISA test on the competitive principle (Franz and Corthier 1981). Microtitration plates (Limbro polystyrene plates) were incubated with 1 per cent glutaraldehyde solution for 1 hour at $4{ }^{\circ} \mathrm{C}$ and rinsed six times with distilled water. Each well received $0.1 \mathrm{ml}$ of rabbit antibodies against pig $\alpha, \gamma$ - and - $\mu$-chains $(10 \mu \mathrm{g}$ in $1 \mathrm{ml} 0.05 \mathrm{~mol}$ $.1^{-1}$ carbonate buffer, $\mathrm{pH} 9.6$ ) which were allowed to incubate at $4{ }^{\circ} \mathrm{C}$ overnight. The plates were then rinsed three times in PBS-Tween.

Samples tested for Ig content were mixed $(1: 1)$ separately with appropriately diluted pure pig IgG, IgA and IgM labelled with alkaline phosphatase, transferred immediately afterwards to plates with coupled rabbit antibodies and incubated for 2 hours at $37^{\circ} \mathrm{C}$. After they were rinsed in PBS-Tween three times, p-nitrophenyl phosphate solution (Sigma - 104 tablets in diathanolamine buffer, $\mathrm{pH}$ 9.6) was added as substrate. After incubation at $37^{\circ} \mathrm{C}$ for 2 hours the intensity of staining of the tested samples was measured spectrophotometrically at $405 \mathrm{~nm}$ directly on polystyrene plates with a Titertek Multiscan (Flow Laboratories) spectrophotometer. Included in each series of measurement were a number of standard samples consisting of solutions of purified pig IgG, IgA and IgM of known concentration which were treated identically to the tested samples. 
The character of the calibration curves constructed from the extinction values of standard samples using a computer (Intertechnique, France) was invariably exponential. Ig concentrations of the tested samples were calculated by means of the calibration curves with the computer and expressed in nanograms of IgG, IgA and IgM per $\mathrm{ml}$ serum and amniotic fluid or per gram organ tested and their mutual ratios were expressed in terms of percentages. The results were evaluated statistically by Student's t-test and the differences in immunoglobulin synthesis between the individual age groups of foetal pigs were assessed.

\section{Results}

\section{0-Day Old Foetuses}

The predominant component of the foetal sera and amniotic fluid was IgG. The mean IgG concentration of the serum was $2459 \mathrm{ng} \cdot \mathrm{ml}^{-1}$ (Table 1) and that of the amniotic fluid was $1253 \mathrm{ng} . \mathrm{ml}^{-1}$, which represents 85.1 per cent and 86.1 per cent, respectively, of the total Ig (Fig. 1). The IgM and IgA concentrations detected in the serum and amniotic fluid were of a lower order of magnitude than that of IgG. In organ suspensions the predominant component was IgM, accounting for 63.9 to 87.6 per cent of the total Ig. The concentration of immunoglobulins in lung suspensions (422.7 $\mathrm{ng} \cdot \mathrm{g}^{-1} \mathrm{IgM}$ ) was of a lower order than that found in the liver and intestine (4324.3 ng.g-1 and $3926 \mathrm{ng} \cdot \mathrm{g}^{-1} \mathrm{IgM}$ ), respectively. IgA accounted for 3.6 to 7.6 per cent of the total Ig, thus being the least represented component in all the samples tested.

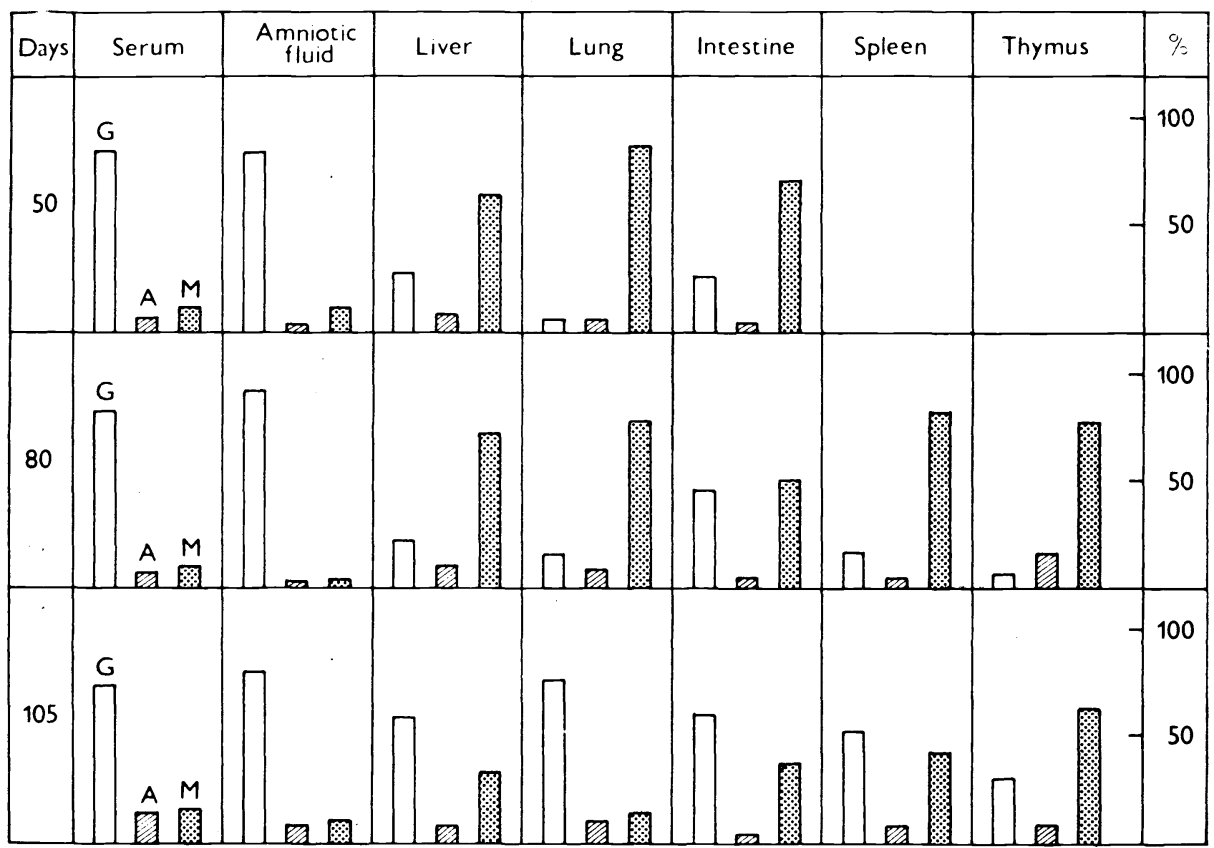

Fig.. 1.

Proportions of IgG, IgA and IgM in the blood serum, amniotic fluid and organs of 50- to 150-day old pig foetuses. 


\section{0-Day Old Foetuses}

Comparison with 50 -day old foetuses showed a significant $(P<0.02$ to $P<$ $<0.001)$ increase in the blood serum concentration of all immunoglobulins. In amniotic fluid a significant $(P<0.05)$ rise was recorded only for IgG. However, mutual ratios of the individual immunoglobulins remained almost unchanged, with IgG predominant (Fig.1). Analysis of organ suspensions demonstrated a significant $(P<0.02)$ rise of IgG in the intestine and a slight $(P<0.05)$ decrease of IgM in the liver. However, the concentration of IgM in the organs of 80-day old foetuses remained the highest of all immunoglobulins. In spleen and thymus suspensions which were prepared as pooled samples of each litter IgM accounted for 81.6 per cent and 76.4 per cent of the total $\mathrm{Ig}$, respectively.

\section{5-Day Old Foetuses}

Compared with the previous groups, this age category of foetal pigs showed almost in all samples a significant $(P<0.05$ to $P<0.001)$ rise in the concentration of all three immunoglobulin classes, particularly in the serum and amniotic fluid where the Ig concentration increased as much as tenfold between 50 and 105 days of gestation (Table 1). An exception to this was the intestinal suspension where a slight decrease was recorded for IgA and $\operatorname{IgM}$. As compared with 50-day and 80-day old foetuses, mutual ratios of the individual immunoglobulins changed in that IgG became the predominant component also in organ suspensions except the thymus; its percentage proportion ranged from 53.5 per cent to 76.1 per cent of the total Ig (Fig. 1). In all the organs under study the proportion of $\operatorname{IgM}$ remained relatively high, compared with the serum and amniotic fluid: in the thymus, IgM accounted for 62 per cent of the total Ig. In the lung suspension the ratios of the individual immunoglobulins were similar to the values recorded for the blood serum.

Table 1

IgG, IgA and IgM concentrations in the blood serum, amniotic fluid (ng $\cdot \mathrm{ml}^{-1}$ ) or organs (ng $\cdot \mathrm{g}^{-1}$ ) of 50- to 150-day old pig foetuses

\begin{tabular}{|c|c|c|c|c|c|c|c|c|c|c|}
\hline \multirow{2}{*}{ Days } & & \multicolumn{3}{|c|}{ Serum } & \multicolumn{3}{|c|}{ Amniotic fluid } & \multicolumn{3}{|c|}{ Liver } \\
\hline & & IgG & IgA & IgM & IgG & IgA & IgM & IgG & IgA & IgM \\
\hline 50 & $\begin{array}{c}\overline{\mathbf{M}} \\
\mathbf{S E}\end{array}$ & $\begin{array}{l}2459 \\
1389\end{array}$ & $\begin{array}{l}130 \\
119\end{array}$ & $\begin{array}{l}229 \\
164\end{array}$ & $\begin{array}{r}1253 \\
799\end{array}$ & $\begin{array}{l}52 \\
39\end{array}$ & $\begin{array}{l}149 \\
132\end{array}$ & $\begin{array}{l}1915 \\
1742\end{array}$ & $\begin{array}{l}521 \\
406\end{array}$ & $\begin{array}{l}4324 \\
1402\end{array}$ \\
\hline 80 & $\underset{\mathbf{P} / 50}{\overline{\mathbf{S E}}}$ & $\begin{array}{r}12100 \\
4795 \\
0.001\end{array}$ & $\begin{array}{l}933 \\
784 \\
0.02\end{array}$ & $\begin{array}{c}1343 \\
782 \\
0.01\end{array}$ & $\begin{array}{l}3406 \\
2089 \\
0.05\end{array}$ & $\begin{array}{r}98 \\
94 \\
\text { NS }\end{array}$ & $\begin{array}{r}129 \\
37 \\
\text { NS }\end{array}$ & $\begin{array}{l}710 \\
490 \\
\text { NS }\end{array}$ & $\begin{array}{r}158 \\
32 \\
\text { NS }\end{array}$ & $\begin{array}{r}2381 \\
758 \\
0.05\end{array}$ \\
\hline 105 & $\begin{array}{c}\bar{M} \\
\mathbf{S E} \\
\mathbf{P} / 50 \\
\mathbf{P} / 80\end{array}$ & $\begin{array}{c}22493 \\
2809 \\
0.001 \\
0.001\end{array}$ & $\begin{array}{l}4344 \\
1277 \\
0.001 \\
0.001\end{array}$ & $\begin{array}{l}4519 \\
1163 \\
0.001 \\
0.001\end{array}$ & $\begin{array}{l}5635 \\
3961 \\
0.001 \\
\text { NS }\end{array}$ & $\begin{array}{r}546 \\
597 \\
0.05 \\
\text { NS }\end{array}$ & $\begin{array}{l}779 \\
515 \\
0.01 \\
0.01\end{array}$ & $\begin{array}{l}9175 \\
2607 \\
0.001 \\
0.001\end{array}$ & $\begin{array}{r}1218 \\
401 \\
0.02 \\
0.001\end{array}$ & $\begin{array}{l}5111 \\
1851 \\
\text { NS } \\
0.01\end{array}$ \\
\hline
\end{tabular}

$\mathrm{M}$ - mean Ig concentration ( $\mathrm{ng} \cdot \mathrm{ml}^{-1}(\mathrm{~g})$ ).

SE - standard error.

$P$ - significance of the difference as against 50-day old foetuses $(P / 50)$ and 80 -day old foetuses $(P / 80)$.

NS - Difference not significant. 


\section{Discussion}

The predominant immunoglobulin in the serum of newborn colostrum-deprived piglets is reportedly IgG whose antigenic determinants are identical with IgG of adult animals (Franěk et al. 1961; Prokešová et al. 1969, 1970). In addition to IgG, precolostral pig sera were found to contain IgA (Prokešová and Rejnek 1971), but doubts have been raised so far as to the presence of IgM except in newborn piglets or foetal pigs 'stimulated antigenically during intra-uterine life (Bourne et al. 1974; Porter and Hill 1970). In our experiments we demonstrated all three immunoglobulin classes in the serum and amniotic fluid of pig foetuses as early as the 50th day of gestation, with $\operatorname{IgM}$ and $\operatorname{IgA}$ in concentrations of a lower order of magnitude than IgG. During the ontogeny of foetal pigs up to 105 days of gestation the concentration of immunoglobulins increased significantly about tenfold, with the mutual ratios of the individual Ig classes being retained. Since in other animal species, too, IgM is regarded as the first Ig synthetized during the ontogenic development, its finding in the sera of foetal pigs seems logical. Moreover, there is evidence to indicate that various organs of foetal pigs and colostrum-deprived piglets as well as lymphocytes isolated from these organs can synthetize all three immunoglobulin classes (Chapman 1974; Prokešová et al. 1979; Hampl et al. 1980). Immunoglobulins have also been demonstrated on the surfaces of circulating lymphocytes in both newborn colostrum-deprived piglets (Ja roško vá 1977) and foetal pigs (Bins et a1. 1972). Considering that in the present study immunoglobulins were detected by the ELISA on the competitive principle (Franz and Corthier 1981), permitting Ig detection down to $1 \mathrm{ng}$, it seems reasonable to suggest that the demonstration of $\operatorname{IgM}$ in foetal pig sera was due particularly to the sensitivity of the method which depends, no doubt, among other things on sufficiently high avidity of the anti- $\mu$ antibodies employed.

In organs such as the liver, spleen, thymus and possibly lung, accumulation occurs of lymphoid cells responsible for Ig secretion and possibly of cells binding

\begin{tabular}{|c|c|c|c|c|c|c|c|c|c|c|c|}
\hline \multicolumn{3}{|c|}{ Lung } & \multicolumn{3}{|c|}{ Intestine } & \multicolumn{3}{|c|}{ Spleen } & \multicolumn{3}{|c|}{ Thymus } \\
\hline IgG & IgA & $\operatorname{IgM}$ & IgG & IgA & $\operatorname{IgM}$ & IgG & IgA & IgM & IgG & IgA & IgM \\
\hline $\begin{array}{l}29 \\
22\end{array}$ & $\begin{array}{r}30 \\
7\end{array}$ & $\begin{array}{r}422 \\
77\end{array}$ & $\begin{array}{r}1432 \\
473\end{array}$ & $\begin{array}{r}216 \\
66\end{array}$ & $\begin{array}{l}3926 \\
1389\end{array}$ & ND & ND & ND & ND & ND & ND \\
\hline $\begin{array}{r}69 \\
52 \\
\text { NS }\end{array}$ & $\begin{array}{r}35 \\
4 \\
\text { NS }\end{array}$ & $\begin{array}{r}371 \\
39 \\
\text { NS }\end{array}$ & $\begin{array}{l}3375 \\
1954 \\
0.02\end{array}$ & $\begin{array}{l}285 \\
120 \\
\text { NS }\end{array}$ & $\begin{array}{r}3776 \\
1119 \\
\text { NS }\end{array}$ & $\begin{array}{c}394 \\
\text { ND } \\
\text { ND }\end{array}$ & $\begin{array}{l}56 \\
\text { ND } \\
\text { ND }\end{array}$ & $\begin{array}{l}1996 \\
\text { ND } \\
\text { ND }\end{array}$ & $\begin{array}{l}324 \\
\text { ND } \\
\text { ND }\end{array}$ & $\begin{array}{l}702 \\
\text { ND } \\
\text { ND }\end{array}$ & $\begin{array}{l}3319 \\
\text { ND } \\
\text { ND }\end{array}$ \\
\hline $\begin{array}{l}3753 \\
1093 \\
0.001 \\
0.001\end{array}$ & $\begin{array}{r}476 \\
166 \\
0.001 \\
0.001\end{array}$ & $\begin{array}{l}704 \\
246 \\
0.02 \\
0.01\end{array}$ & $\begin{array}{c}2961 \\
1796 \\
0.05 \\
\text { NS }\end{array}$ & $\begin{array}{r}117 \\
77 \\
0.05 \\
0.02\end{array}$ & $\begin{array}{l}1860 \\
1473 \\
0.05 \\
0.05\end{array}$ & $\begin{array}{l}6922 \\
\text { ND } \\
\text { ND } \\
\text { ND }\end{array}$ & $\begin{array}{l}767 \\
\text { ND } \\
\text { ND } \\
\text { ND }\end{array}$ & $\begin{array}{l}5238 \\
\text { ND } \\
\text { ND } \\
\text { ND }\end{array}$ & $\begin{array}{l}5908 \\
\text { ND } \\
\text { ND } \\
\text { ND }\end{array}$ & $\begin{array}{l}1345 \\
\text { ND } \\
\text { ND } \\
\text { ND }\end{array}$ & $\begin{array}{l}11835 \\
\text { ND } \\
\text { ND } \\
\text { ND }\end{array}$ \\
\hline
\end{tabular}


Ig at the membrane which were demonstrated in foetal pigs even during their early intra-uterine life (Chapman et al. 1974; Jarošková 1977) and were found to produce or bind mainly IgM.

In contrast to foetal sera and amniotic fluid, organ suspensions prepared from 50-day old foetuses had IgM as the predominart component. In our view, IgM bound to the cell membrane is released into the solution as organ suspensions are prepared and can be determined by the ELISA. Provided that this is the case, our results are in keeping with the observations of the last-mentioned authors.

During the ontogenic development of foetal pigs from 50 to 105 days of gestation significant changes were demonstrated in the present study concerning both the rise of Ig concentration in all the organs under study, except the intestine, and changes in mutual ratios of the individual immunoglobulins. By the 105th day IgG had become the predominant Ig in all the cases under study except the thymus. Considering the evidence that in newborn piglets lymphocyte numbers responsible for the synthesis of $\operatorname{IgG}, \operatorname{IgM}$ and $\operatorname{IgA}$ are of the same order of magnitude (Prokešová et al. 1979), the rise in IgG can be accounted for primarily by enhanced secretory activity of lymphocytes responsible for its production. However, consideration should be given to the fact that some organs of 105-day old foetuses, particularly the liver, spleen and lung, had a higher blood content than those of the younger foetuses and our results may therefore be partly influenced by the presence of circulating IgG. Nevertheless, the mutual ratios of the individual immunoglobulins in the organs (except the lung) were considerably different from those found in the blood serum.

A point not to be neglected in evaluating the results of the analysis of immunoglobulin content is the fact that IgG produced by foetal pigs is a heterogenous mixture of approximately four different molecule kinds, only about 40 per cent of which correspond in thir molecular weight and $\gamma$ - and L-chain content to the IgG of adult animals (Franěk 1961; Franěk and Řiha 1964; Prokešová and Rejnek 1973). The remaining components of lower molecular weight are apparently fragments of complete IgG molecules which according to the aforementioned writers also contain $\gamma$ - and L-chains and react therefore with anti- $\gamma$ antibodies which we, too, employed for the ELISA. Since our data on IgG quantities in the foetal material are based upon calibration curves constructed from the standards of IgG solution of adult animals, they rather express the sum of a heterogenous molecule population having antigenic IgG determinants of adult animals.

The present results confirmed that foetal pigs can synthetize all three Ig classes which, however, are not released in equal quantities into the blood circulation by lymphoid cells. IgM is secreted in a substantially smaller quantity than IgG and, without a major antigenic stimulus, remains enclosed in lymphoid cells or is firmly fixed to their membrane (Prokešová and Rejnek 1976; Jarošková 1977).

\section{Syntéza imunoglobulinů $G, M, A$ v ontogenezi u prasečích fétů}

$\mathrm{K}$ detekci prasečích imunoglobulinů byl použit modifikovaný mikro-ELISA-test na kompetitivním principu. $\mathrm{V}$ krevním séru, amniové tekutině a $\mathrm{v}$ suspenzích orgánů padesátidenních prasečích fétů byly prokázány IgG, IgM a IgA. V období od 50 . do 105 . dne stáŕi plodů převládal v krevním séru a amniové tekutině IgG, naproti tomu v suspenzích fetálních orgánů tvořil do 80 . dne predo- 
minantní složku IgM. Ve 105. dnu se vzájemný poměr imunologlobulinů v suspenzích fetálních orgánů s vyjímkou thymu změnil ve prospěch IgG. $V$ průběhu sledovaného období byly statisticky prokázány změny koncentrace Ig.

\section{Синтез иммуноглобулинов $\mathbf{G}, \mathbf{M}, \mathbf{A}$ в онтногенезе свиных плодов}

Для обнаружения иммуноглобулинов свиней был использован модифицированный микро-ЭЛИСА-тест на компетитивном принщипе. В кровяной сыворотке, амниотической жидкости и суспензии органов плодов свиней в возрасте пятидесяти суток были установлены иммуноглобулины G, M, А.

B период с 50 до 105 день возраста плодов преобладающим в кровяной сыворотке и амниотической жидкости стал иммуноглобулин $G$, в противовес әтому, преобладающим компонентом в суспензиях органов плодов до $80 \mathrm{cy-}$ ток возраста стал иммуноглобулин М. На 105 сутки взаимное соотношение иммуноглобулинов в суспензиях органов плодов - за исключением вилочговой железы - изменилось в пользу иммуноглобулина G. B течение исследуемого были статистически установлены изменения в концентрации иммуноглобулинов.

\section{References}

AVRAMEAS, S.: Coupling of enzymes to proteins with glutaraldehyde.Use of conjugates for the detection of antigens and antibodies. Immunochemistry, 6, 1969: 43-52.

AXEN, R. - PORATH, J. - ERNBACK, S.: Chemical coupling of peptides and proteins to polysaccharides by means of cyanogen halides. Nature (London), 213, 1967: 1302-1304.

BINNS, R. M. - FEINSTEIN, A. - GURNER, B. W. - COOMBS, R. R. A.: Immunoglobulin determinants on lymphocytes of adult, neonatal and foetal pigs. Nature, 239, 1972: 114 až 116 .

BOURNE, F. J. - CURTIS, J. - JOHNSON, R. H. - COLLINES, D. F.: Antibody formation in porcine fetuses. Res. vet. Sci., 16, 1974: 223-227.

FRANĚK, F. - RfHA, I. - ŠTERZL, J.: Characteristic of globulin, lacking antibody properties in newborn pigs. Nature, 189, 1961: 1020-1022.

FRANĚK, F. - KfHA, I.: Purification and structural characterisation of $5 \mathrm{~S}$ globulin in newborn pigs. Immunochemistry, 1, 1964: 49-63.

FRANĚK, F. - ZORINA, O. M.: On protein CX isolation and characterisation of $\pi$ and $\lambda$ chains representing structural types of pig $\gamma-$ globulin light chains. Collect. Czech. Che. Commun. 32, 1967: 3229-3231.

FRANZ, J. - CORTHIER, G.: Measurement of porcine faecal IgA, IgG and IgM levels by a competitive enzyme-linked immunosorbentassay. Clin. exp. Immunol., 44, 1981: 645-649.

FRANZ, J. - MENŠfK, J. - POKORNÝ, J.: Detection of antibodies and characterisation of immunoglobulins in precolostral piglet sera. Acta vet. Brno, 40, 1971: 75-80.

HAMPL, J. - FRANZ, J. - ŠTĚPÁNEK, J. - HOLUB, A. - MENŚfK, J.: Immunoglobulin proteosynthesis in organ cultures from newborn piglets. Acta vet. Brno, 49, 1980: 114-116.

CHAPPMANN, H. A. - JOHNSON, J. S. - COOPER, M. D.: Ontogeny of Peyers's patches and immunoglobulin-containing cells in pigs. J. Immun., 112, 1974: 555-569.

JAROSKKOVA, L.: Membrane receptors on lymphocytes. Ontogenic studies in the foetal pig. Acta vet. Brno, 46, 1977: Suppl 4, 55-82.

MENŠfK, J. - FRANZ, J.: The immunologic behaviour of newborn piglets. II. Immunoglobulins and specific antibodies to Myxovirus influenzae suis in the precolostral serum of piglets and in the colostrum of their dams. Docum. vet., Brno, 7, 1969: 137-150.

METZGER, J. J. - HOUDAYER, M.: Subclasses of porcine immunoglobulins G. Production of subclass specif ic antisera with S-sulfonated gamma chains. Eur. J. Immun., 2, 1972: 127-130.

PORTER, P.: Transfer of immunoglobulins IgG, IgA and IgM to lacteal secretions in the parturient sows and absorption by the neonatal piglets. Biochim. biophys. Acta, 181, 1969: 381-392.

PORTER, P. - HILL, I.R.: Serological changes in immunoglobulins IgA, IgG, IgM and Escherichia coli antibodies in young pigs. Immunology, 18, 1970: 565-573. 
PROKEŠOVA, L. - REJNEK, J. - ŠTERZL, J. - TRAVNAČEK, J.: Isolation and characterisation of immunoglobulins in the serum of precolostral piglets. Folia microbiol., 14, 1969: $352-376$.

PROKESOVA, L. - REJNEK, J.: Active synthesis of IgA in newborn precolostral piglets. Folia microbiol., 16, 1971: 476-478.

PROKEŠOVA, L. - REJNEK, J.: Molecular heterogeneity of newborn piglets IgG. Immunochemistry 10, 1973: 607-609.

PROKESOVA, L. - REJNEK, J.: Ontogenic development of immunoglobulins and antibodies in pigs. Proc. of the Symposium: Symposium on protein structure and evolution. Smolenice CSSR, May 28-31, Marcel Dekker INC., New York-Basel, 1976: 401-411.

PROKESSOVA, L. - KOVAŔ̛, F. - JAROŠKOVÁ, L. - KOSTKA, J. - HAVRANEK, T. - REJNEK, J.: Ontogeny of immunoglobulin synthesis. Production of IgM, IgG and IgA in newborn piglets. Develop. Comp. Immunol., 3, 1979: 127-138.

SOKOL, A. - DURKOVIČ, V.: Dynamics of immunoglobulin found in the serum of pigs in the last third of intrauterine life. Folia microbiol., 12, 1967: 411 (abstr.)

STERZL, J $/$ - KOSTKA, J. - RfHA, J. - MENDEL, L.: Attempts to determine the formation and characterisation of $\gamma$-globulin and immune antibodies in young pigs reared without colostrum. Folia microbiol., 5, 1960: 29-45.

ŚTERZL, J. - SILVERSTEIN, A. M.: Developmental aspects of imunity. Advances in Immunology, 6, 1967: 337-459. 